\title{
FIRM SIZE, PROFITABILITAS, LEVERAGE, JENIS PERUSAHAAN AUDIT, JENIS INDUSTRI, PENELITIAN DAN PENGEMBANGAN SEBAGAI DETERMINAN PENGUNGKAPAN MODAL INTELEKTUAL (ICD)
}

\author{
FIRM SIZE, PROFITABILITY, LEVERAGE, TYPE OF AUDIT FIRM, INDUSTRY \\ TYPE, RESEARCH AND DEVELOPMENT AS A DETERMINANT OF INTELLECTUAL \\ CAPITAL DISCLOSURES (ICD) \\ W. Sariningsih, F. E. N. Saputro \\ Program Studi Akuntansi, Fakultas Hukum dan Bisnis, Universitas Duta Bangsa Surakarta \\ Program Studi RMIK, Fakultas Ilmu Kesehatan, Universitas Duta Bangsa Surakarta \\ wiwik_sariningsih@udb.ac.id, facruddinedi@udb.ac.id
}

\begin{abstract}
This study purposed to examine the determinants of intellectual capital disclosure. Firm size, profitability, leverage, type of audit firm, insdustry type, research and development used in this paper as a determinants of intellectual capital disclosure (ICD). The population used in this study are companies listed at Indonesian stock exchange (IDX) in 2018. Purposive sampling methods were used in this study with sample result 276 firm consisting of various industries types that listed in IDX. After the outlier data result 261 firm that used to be a sample. In this paper the data were analized using IBM SPSS statistic. Classic assumption test was have done before regression analysis test. The results of this study indicate that firm size, leverage, type of audit firm, industry type, research and development significantly affected to intellectual capital disclosure. Profitability variable show different result. Profitability have not affected to intellectual capital disclosure. In addition, the result of this paper give an evidence that firm which used big four audit firm, show more intellectual capital disclosure. Firm in category high intellectual capital (high-IC) intensive industries have more intellectual capital disclosure. Furthermore, firm that conduct research and development were proven more intellectual capital disclosure.
\end{abstract}

Keywords: Intellectual Capital Disclosure, Determinant, Type of Audit Firm, Industry Type, Research and Development

\section{ABSTRAK}

Penelitian ini bertujuan untuk menguji determinan (faktor-faktor penentu) pengungkapan modal intelektual. Firm size, profitabilitas, leverage, jenis perusahaan audit, jenis industri, penelitian dan pengembangan digunakan dalam penelitian ini sebagai determinan pengungkapan modal intelektual. Penelitian ini menggunakan populasi seluruh perusahaan yang tercatat di Bursa Efek Indonesia (BEI) tahun 2018. Penelitian ini menggunakan metode purposive sampling untuk menentukan sampel yang akan digunakan dan menghasilkan sampel akhir berjumlah 276 perusahaan yang meliputi berbagai sektor perusahaan. Setelah dilakukan outlier data menghasilkan 261 perusahaan yang dijadikan sampel. Data dalam penelitian ini dianalisis menggunakan IBM SPSS statistic. Uji asumsi klasik telah dilakukan sebelum uji analisis regresi. Hasil penelitian ini menunjukkan bahwa firm size, leverage, jenis perusahaan audit, jenis industri, penelitian dan pengembangan berpengaruh secara signifikan terhadap pengungkapan modal intelektual. Variabel profitabilitas menunjukkan hasil yang berbeda. Profitabilitas tidak berpengaruh terhadap pengungkapan modal intelektual. Penelitian ini juga membuktikan bahwa perusahaan yang diaudit oleh Kantor Akuntan Publik (KAP) Big Four menunjukkan pengungkapan modal intelektual yang lebih banyak. Perusahaan dengan kategori jenis industri (high-IC) intensive industries memiliki pengungkapan modal intelektual lebih banyak. Lebih lanjut, perusahaan yang melakukan penelitian dan pengembangan terbukti lebih banyak melakukan pengungkapan modal intelektual.

Kata kunci: Pengungkapan Modal Intelektual, Determinan, Jenis Perusahaan Audit, Jenis Industri, Penelitian dan Pengembangan 


\section{PENDAHULUAN}

Perkembangan ekonomi global menurut Saleh et al. (2009) ditandai dengan adanya berbagai industri baru dengan basis pengetahuan. New economy atau ekonomi baru biasa disebut dengan ekonomi berbasis pengetahuan muncul akibat globalisasi dan perkembangan teknologi informasi komunikasi. Investasi yang dilakukan perusahaan dalam hal penelitian pengembangan, inovasi dalam hal produksi atau pembuatan produk baru maupun pemasaran, pengembangan kewirausahaan pada industri berbasis teknologi, pengembangan teknologi informasi dan komunikasi, pemberian beasiswa kepada karyawan untuk peningkatan pendidikan ke jenjang yang lebih tinggi, meningkatnya ketrampilan merupakan beberapa unsur yang ada pada ekonomi berbasis pengetahuan.

Perusahaan yang melakukan inovasi akan memiliki keunggulan daya saing dibandingkan perusahaan lainnya. Artinya perusahaan akan melakukan penelitian dan pengembangan agar dapat terus berinovasi dan tidak ketinggalan jaman. Sumberdaya yang memadai baik sumberdaya manusia maupun sumberdaya modal dapat menunjang adanya inovasi perusahaan secara terus menerus. Ekonomi baru yang semakin berkembang ini sangat dipengaruhi oleh informasi dan pengetahuan yang dapat mendorong perusahaan untuk lebih memperhatikan modal intelektual (Tan et al., 2007).

Modal fisik (physical capital), modal keuangan (financial capital), dan modal intelektual (intellectual capital) merupakan modal yang sangat berarti bagi perusahaan (Utomo dan Chariri, 2015). Modal fisik dan modal keuangan biasanya akan sangat diperhatikan perusahaan, namun ada satu modal lagi yang harus menjadi perhatian perusahaan yaitu modal intelektual. Modal intelektual merupakan modal yang dianggap sebagai sumber keunggulan kompetitif bagi organisasi, yang dapat menggerakkan inovasi dan kreativitas (Taliyang et al., 2011). Perusahaan yang memiliki keunggulan kompetitif akan lebih menjadi perhatian investor karena investor akan menilai bahwa perusahaan tersebut dimasa yang akan datang mampu bertahan dalam persaingan bisnis.

Susandra (2015) Para pemakai laporan keuangan sangat memerlukan informasi terkait modal intelektual karena dapat digunakan untuk menilai prospek perusahaan di masa yang akan datang, namun informasi tersebut tidak ada dalam laporan keuangan. Laporan keuangan tidak dapat memuat semua informasi dalam bentuk deskripsi sehingga perusahaan perlu menyampaikan informasi deskripsi terkait modal intelektual melalui pengungkapan. Pengungkapan merupakan upaya perusahaan sebagai bentuk transparansi informasi kepada para stakeholders perusahaan terkait informasi-informasi penting yang tidak dapat disajikan dalam laporan keuangan dan berguna untuk pengambilan keputusan. Terdapat 2 bentuk pengungkapan yaitu pengungkapan wajib dan pengungkapan sukarela.

Melani (2017) Pengungkapan modal intelektual merupakan pengungkapan yang dikategorikan sebagai pengungkapan sukarela sehingga perusahaan diberi kebebasan untuk menyampaikan pengungkapan modal intelektual atau tidak menyampaikan. Pengungkapan modal intelektual diharapkan sebagai bentuk transparansi informasi kepada para stakeholders, dan sebagai salah satu sarana untuk mengungkapkan informasi yang lebih rinci yang tidak dapat dicantumkan dalam laporan keuangan.

Pengungkapan modal intelektual terdiri dari tiga informasi diantaranya yaitu a) human capita, b) structural capital dan c) relational capital. Zurnali (2010) mendefinisikan human capital sebagai pengetahuan individual yang dimiliki para anggota organisasi. Structural capital adalah pengetahuan yang berkaitan dengan berbagai jenis pemenuhan relasi atau hubungan dalam pengelolaan perusahaan dengan suatu cara yang terkoordinasi. Relational capital merupakan pengetahuan yang menyeluruh 
terkait bidang pemasaran dan bidang yang berhubungan dengan pelanggan. Informasi yang terkait dengan pengungkapan modal intelektual oleh perusahaan akan bermanfaat untuk para investor dalam hal pembuatan keputusan dalam melakukan investasi. Informasi rinci yang disampaikan perusahaan dan ditangkap oleh investor akan berguna untuk meminimalisasi kesalahan investor dalam pembuatan keputusan investasi(Hutomo et.al, 2019).

Standar akuntansi yang belum ada terkait pengungkapan modal intelektual menjadi permasalahan dari pengungkapan modal intelektual ini, sehingga belum adanya kewajiban untuk melaporkan pengungkapan modal intelektual. Bruggen et al. (2009) menyatakan bahwa terdapat permasalahan terkait dengan pengungkapan modal intelektual yaitu pedoman atau peraturan yang belum ada tentang bagaimana modal intelektual dilaporkan dan dilakukan pengukuran secara spesifik.

Karakteristik perusahaan seperti firm size, profitabilitas, leverage, jenis perusahaan audit, jenis industri, penelitian dan pengembangan dapat mempengaruhi pengungkapan modal intelektual secara sukarela. Beberapa penelitian tentang faktor-faktor yang mempengaruhi pengungkapan modal intelektual telah dilakukan, namun ada beberapa variabel yang memiliki hasil tidak konsisten. Penelitian ini bertujuan untuk menguji determinan pengungkapan modal intelektual dan diharapkan dapat berkontribusi untuk menggeneralisasi hasil dari variabelvariabel yang hasilnya tidak konsisten. Penelitian ini juga memasukkan variabel penelitian dan pengembangan sebagai determinan pengungkapan modal intelektual.

Penelitian ini menggunakan teori agensi (agency theory) dan teori sinyal (signaling theory) untuk menghubungkan masing-masing hipotesis. Jensen dan Meckling (1976) menjelaskan bahwa hubungan keagenan merupakan suatu kontrak dimana satu atau lebih orang prinsipal yang memberikan wewenang kepada orang lain yaitu agen untuk melakukan suatu jasa atas nama prinsipal dan membuat keputusan yang terbaik bagi prinsipal dalam mengelola perusahaan. Teori agensi memberikan asumsi bahwa dengan pengungkapan dapat digunakan untuk meminimalisasi biaya keagenan yang timbul. Hubungan antara agen dan prinsipal biasanya akan memunculkan benturan kepentingan yang biasa disebut sebagai conflict of interest yang terjadi ketika prinsipal tidak dapat menjamin kepastian bahwa agen bekerja untuk memaksimalkan kesejahteraan prinsipal. Konflik antara prinsipal dan agen inilah yang dapat menimbulkan biaya keagenan (agency cost). Jensen dan Meckling (1976) menyatakan bahwa biaya keagenan ada 3, yaitu monitoring cost, bonding cost, dan residual loss.

Teori sinyal dapat diartikan sebagai suatu teori yang menyatakan bahwa sebuah organisasi atau perusahaan akan melakukaaan usaha untuk memberikan informasi yang dapat menjadi sinyal positif kepada para stakeholders (Oliveira et al., 2006). Keberadaan teori sinyal diharapkan akan dapat memberikan informasi secara berimbang untuk menghindari adanya informasi asimetris yang merupakan kondisi ketika salah satu pihak memiliki informasi lebih baik atau lebih banyak daripada pihak lain.

\section{Modal Intelektual}

Roos et al. (1997) mendefinisikan modal intelektual sebagai semua pengetahuan berbasis proses dan aset tidak berwujud yang biasanya tidak ditampilkan di neraca, dan dapat dimanfaatkan untuk meningkatkan nilai masa depan. Stewart (1997) dalam Tan et al. (2007) mengklasifikasikan modal intelektual menjadi 3, yaitu: human capital, structural capital, dan customer atau relational capital.

\section{Pengungkapan Modal Intelektual}

Pengungkapan modal intelektual merupakan upaya untuk menyampaikan 
informasi yang berhubungan dengan modal intelektual (human capital, structural capital, dan relational capital) oleh perusahaan ke dalam laporan tahunan dan ditujukan untuk para pengguna laporan keuangan atau stakeholders perusahaan (Reditha dan Mayangsari, 2016).

\section{PENGEMBANGAN HIPOTESIS}

Pengaruh firm size terhadap pengungkapan modal intelektual

Firm size dapat diartikan sebagai ukuran perusahaan yang biasanya dinyatakan dalam skala perusahaan besar dan perusahaan kecil. Firm size yang semakin besar akan memiliki tuntutan yang besar dari masyarakat untuk dapat mengungkapan informasi secara detail dan sukarela. Masyarakat akan lebih menyoroti perusahaan besar dikarenakan masyarakat memiliki harapan bahwa perusahaan besar akan memiliki performa yang lebih baik (Utomo, 2015). Alasan tersebut yang dijadikan dasar oleh perusahaan besar dalam melakukan pengungkapan informasi yang lebih lengkap pada laporan tahunan, namun tidak begitu diperhatikan oleh perusahaan kecil.

Teori keagenan dapat menjelaskan keterkaitan antara firm size dan pengungkapan modal intelektual. Perusahaan besar pada umumnya memiliki biaya keagenan yang lebih tinggi dibandingkan perusahaan kecil. Salah satu cara untuk mengurangi biaya keagenan yaitu dengan melakukan pengungkapan sukarela secara lebih lengkap dalam laporan tahunan. Informasi yang dapat diungkapkan dapat berupa informasi terkait informasi modal intelektual.

$$
\text { Puteri dan Chariri (2016), }
$$

Suhardjanto dan Wardhani (2010), Bruggen et al. (2009) merupakan beberapa peneliti yang telah melakukan penelitian untuk menguji pengaruh ukuran perusahaan dan pengungkapan modal intelektual yang menunjukkan hasil bahwa ukuran perusahaan memiliki pengaruh positif terhadap pengungkapan modal intelektual, sehingga hipotesis yang diusulkan dalam penelitian ini adalah

\section{H1: Firm size berpengaruh positif terhadap pengungkapan modal intelektual}

\section{Pengaruh profitabilitas terhadap pengungkapan modal intelektual}

Sudana, 2011 mengartikan profitabilitas sebagai kemampuan suatu perusahaan dalam memperoleh laba dengan memanfaatkan sumber daya (aset, modal atau penjualan) yang dimiliki perusahaan. Profitabilitas perusahaan yang semakin tinggi setiap periodenya dapat menjadi sinyal positif yang dapat mempengaruhi investor dalam pembuatan keputusan investasi. Teori sinyal dapat menjelaskan keterkaitan antara profitabilitas dan pengungkapan modal intelektual. Informasi yang tidak bersifat wajib akan diungkapkan lebih banyak dalam laporan tahunan oleh perusahaan yang memiliki laba yang tinggi karena laba yang semakin tinggi dapat menjadi sinyal positif bagi para stakeholders. Suhardjanto dan Wardani (2010) telah melakukan penelitian yang berkaitan dengan pengaruh profitabilitas dan pengungkapan modal intelektual. Hasil penelitian tersebut adalah memberikan bukti bahwa profitabilitas berpengaruh positif terhadap pengungkapan modal intelektual, sehingga hipotesis yang diusulkan dalam penelitian ini adalah

H2: Profitabilitas berpengaruh positif terhadap pengungkapan modal intelektual

\section{Pengaruh leverage terhadap pengungkapan modal intelektual.}

Leverage merupakan rasio yang menggambarkan perbandingan tingkat utang yang dimiliki perusahaan terhadap total aset yang dimiliki perusahaan. Perusahaan yang memiliki tingkat utang yang tinggi biasanya akan menyajikan informasi yang lebih detail kepada kreditor dan pemegang saham. Perusahaan dengan tingkat utang yang tinggi akan menyebabkan monitoring cost yang tinggi. Teori keagenan dapat menjelaskan 
keterkaitan antara anatara leverage dan pengungkapan modal intelektual. Pengungkapan modal intelektual diharapkan dapat meminimalisasi monitoring cost perusahaan yang tinggi. Utomo dan Chariri (2015), Whiting dan Woodcock (2011) telah melakukan penelitian berkaitan dengan pengaruh leverage terhadap pengungkapan modal intelektual dan memberikan bukti leverage tidak berpengaruh dengan pengungkapan modal intelektual. Penelitian lainnya yang dilakukan Dammak et al. (2008), dan White et al. (2007) memiliki hasil yang berbeda yaitu bahwa leverage berpengaruh positif terhadap pengungkapan modal intelektual. Perbedaan hasil penelitian sebelumnya menjadi dasar untuk meneliti kembali pengaruh variabel leverage terhadap pengungkapan modal intelektual. Penelitian ini mengusulkan hipotesis bahwa leverage berpengaruh positif terhadap pengungkapan modal intelektual.

\section{H3: Leverage berpengaruh positif terhadap pengungkapan modal intelektual.}

\section{Pengaruh jenis perusahaan audit terhadap pengungkapan modal intelektual}

Auditor dapat diartikan sebagai seseorang yang kompeten dan independen serta memiliki kualifikasi tertentu dalam melakukan audit atas laporan keuangan suatu perusahaan. Auditor memiliki peran penting untuk menilai kewajaran laporan keuangan perusahaan. Kualitas perusahaan audit menjadi salah satu pertimbangan penting bagi investor untuk menilai kewajaran suatu laporan keuangan. Perusahaan audit berdasarkan reputasinya dapat dikelompokkan menjadi KAP Big Four dan non Big Four. KAP Big Four dianggap memiliki sumberdaya lebih baik dari KAP Non Big Four dan dianggap memberikan kualitas audit yang lebih tinggi (Khasanah \& Nahumury, 2013).
Teori agensi dapat menjelaskan keterkaitan antara jenis perusahaan audit dan pengungkapan modal intelektual. Audit merupakan salah satu cara yang digunakan perusahaan untuk mengurangi biaya keagenan. Investor dan masyarakat menganggap bahwa perusahaan yang diaudit oleh KAP Big Four atau yang berafiliasi dengan KAP Big Four akan melakukan pengungkapan informasi modal intelektual yang lebih banyak dibandingkan perusahaan yang diaudit oleh KAP non Big Four. Manajemen perusahaan dapat termotivasi oleh kantor akuntan publik yang bereputasi (KAP yang besar) dalam melakukan pengungkapan informasi dengan lebih lengkap (Puteri dan Chariri, 2016). Woodcock dan Whiting (2009) telah melakukan penelitian yang berkaitan dengan pengaruh jenis perusahaan audit terhadap pengungkapan modal intelektual dan memberikan bukti bahwa bahwa jenis perusahaan audit memiliki pengaruh terhadap pengungkapan modal intelektual. Hipotesis yang diusulkan dalam penelitian ini adalah

H4: Perusahaan yang diaudit oleh KAP Big Four atau yang berafiliasi dengan KAP Big Four akan melakukan pengungkapan modal intelektual lebih banyak daripada perusahaan yang diaudit oleh KAP non Big Four.

\section{Pengaruh jenis industri terhadap pengungkapan modal intelektual}

Industri dapat diartikan sebagai kelompok perusahaan yang memiliki karakteristik usaha yang sejenis. Menurut Utomo (2015) jenis industri dapat dilihat dari jenis aktivitas atau kegiatan yang dilakukan perusahaan. Penelitian ini mengadopsi pengklasifikasian industri oleh Woodcock dan Whiting (2009) yang didasarkan pada pengklasifikasian Global Industry Classification Standard (GICS). Industri diklasifikasikan menjadi dua kelompok yaitu high-IC intensive industries dan low-IC intensive industries. High-IC intensive industries terdiri dari berbagai industri yang menerapkan teknologi dan pengetahuan. Low-IC intensive industries 
terdiri dari berbagai industri yang masih menerapkan sistem tradisional. Industri yang modal intelektualnya tinggi berarti termasuk industri yang padat modal intelektual, sehingga akan mengungkapkan informasi modal intelektual lebih banyak dalam laporan tahunan.

Teori sinyal dapat menjelaskan keterkaitan antara jenis industri dan pengungkapan modal intelektual. Puteri dan Chariri (2016) telah melakukan penelitian berkaitan dengan pengaruh jenis industri dan pengungkapan modal intelektual dan memberikan bukti bahwa jenis industri berpengaruh terhadap banyak sedikitnya pengungkapan modal intelektual. Hipotesis yang diusulkan dalam penelitian ini adalah

H5: Perusahaan yang termasuk highIC intensive industries akan melakukan pengungkapan modal intelektual lebih banyak daripada perusahaan yang termasuk low-IC intensive industries.

\section{Pengaruh penelitian dan pengembangan terhadap pengungkapan modal intelektual}

Penelitian dan pengembangan dapat diartikan sebagai pendekatan yang dilakukan untuk menciptakan sebuah produk baru atau perbaikan dan penyempurnaan produk yang telah ada sebelumnya (Sukmadinata, 2008). Perusahaan akan melakukan penelitian dan pengembangan sebagai suatu upaya dalam menghasilkan sebuah inovasi dan agar dapat bertahan dalam persaingan bisnis. Para investor akan memberi perhatian lebih kepada perusahaan yang melakukan penelitian dan pengembangan karena investor yakin bahwa perusahaan yang melakukan penelitian dan pengembangan dapat menangkap peluang sehingga dapat bertahan dalam persaingan bisnis. Penelitian dan pengembangan merupakan salah satu investasi jangka panjang perusahaan karena manfaatnya tidak bisa dirasakan secara langsung.

Keterkaitan antara penelitian dan pengembangan dengan pengungkapan modal intelektual dapat dijelaskan oleh teori sinyal. Penelitian dan pengembangan merupakan salah satu sinyal positif apabila para stakeholders dapat menangkapnya. Penelitian dan pengembangan dapat menjadi faktor yang penting di era ekonomi baru berbasis pengetahuan yang akan berguna untuk penciptaan modal intelektual (Brosnan \& Flynn, 2004). Informasi terkait dengan penelitian dan pengembangan dapat diketahui investor dan dapat digunakan untuk pembuatan keputusan bisa diperoleh melalui pengungkapan secara sukarela dalam laporan tahunan. Hipotesis yang diusulkan dalam penelitian ini adalah

\section{H6: Penelitian dan pengembangan berpengaruh positif terhadap pengungkapan modal intelektual}

\section{METODE PENELITIAN}

Penelitian ini merupakan penelitian kuantitatif dengan menggunakan data sekunder. Data yang digunakan dalam penelitian ini diperoleh dari situs Bursa Efek Indonesia yaitu www.idx.co.id dan website resmi masing-masing perusahaan yang berupa laporan keuangan dan laporan tahunan perusahaan tahun 2018. Teknik sampling pada penelitian ini menggunakan teknik purposive sampling yaitu teknik pengambilan sampel dengan menggunakan kriteria tertentu dan dengan tujuan tertentu. Pemilihan sampel pada penelitian ini menggunakan metode purposive sampling berdasarkan kriteria yang telah ditetapkan.

\section{Variabel Penelitian}

Variabel-varibel yang digunakan dalam penelitian ini terdiri dari firm size, profitabilitas, leverage, jenis perusahaan audit, jenis industri, penelitian dan pengembangan serta pengungkapan modal intelektual (ICD). Berikut ini merupakan penjelasan definisi beserta pengukuran masing-masing variabel:

1. Firm size (SIZE) merupakan skala perusahaan yang dapat dibagi menjadi perusahaan besar dan perusahaan kecil. 
Ukuran perusahaan diperoleh dari total aset perusahaan yang dilogaritma naturalkan.

2. Profitabilitas diartikan sebagai seberapa besar kapabalitas perusahaan dalam memperoleh laba. Return On Assets (ROA) digunakan sebagai proksi dari profitabilitas dalam penelitian ini. ROA diperoleh dari perbandingan laba bersih perusahaan terhadap total aset perusahaan.

3. Leverage merupakan rasio yang mencerminkan seberapa besar tingkat utang terhadap total aset perusahaan (debt to total asset ratio atau DAR).

4. Jenis perusahaan audit merupakan pengelompokan perusahaan audit menjadi KAP big four dan KAP non big four. Variabel ini diukur dengan kode dummy, yaitu angka 1 (KAP big four ) dan 0 (KAP non big four).

5. Jenis industri merupakan sekelompok perusahaan yang memiliki karakteristik usaha yang sejenis. Jenis industri berdasarkan GICS dibagi menjadi dua yaitu industri High-IC Intensive dan Low-IC Intensive. Variabel ini diukur dengan kode dummy. Angka 1 untuk industri yang masuk kategori high-IC intensive dan angka 0 untuk industri yang masuk kategori low-IC intensive.

6. Penelitian dan pengembangan dapat diartikan sebagai suatu langkah perusahaan dalam menghasilkan produk baru atau penyempurnaan produk yang sudah ada sebelumnya. Kode dummy juga digunakan mengukur variabel ini. Angka 1 untuk perusahaan yang melakukan kegiatan penelitian dan pengembangan dan angka 0 untuk perusahaan yang tidak melakukan penelitian dan pengembangan.

Pengungkapan modal intelektual adalah pengungkapan terkait informasi modal intelektual yang dimiliki perusahaan. Pengungkapan modal intelektual diukur dengan framework ICD-In yang diadopsi dari pengembangan framework ICD oleh Ulum (2015) dan merupakan modifikasi skema yang pernah dibuat Guthrie et al. (1999). Item pengungkapan modal intelektual terdiri dari 36 item yang digunakan untuk mengetahui luas pengungkapan modal intelektual yang dibagi menjadi 3 yaitu human capital, structural capital, relational capital. Penelitian ini mengadopsi cara identifikasi item-tem pengungkapan modal intelektual yang dilakukan oleh Guthrie et al. (1999) yaitu dengan menggunakan pengkodean numerik yang terdiri dari 4 cara. Kode numerik yang digunakan adalah angka 0 sampai 3. Angka 0 jika item tidak diungkapkan dalam laporan tahunan, angka 1 jika item diungkapkan dalam bentuk narasi, angka 2 jika item diungkapkan dalam bentuk numerik, angka 3 jika item diungkapkan dengan nilai moneter. Berdasarkan Hooks \& Staden (2011) untuk memperoleh indeks pengungkapan modal intelektual maka dilakukan penjumlahan skor item-item yang diungkapkan dibagi dengan skor kumulatif keseluruhan pengungkapan.

$$
\text { ICD }=\frac{\text { Total Skor Pengungkapan }}{\text { Skor Kumulatif }(64)}
$$

\section{Metode Analisis Data}

Penelitian ini menggunakan analisis regresi. Analisis regresi digunakan untuk menguji sejauh mana pengaruh hubungan antara dua variabel atau lebih dengan kata lain berguna untuk mengetahui hubungan antara variabel dependen dan variabel independen. Analisis statistik deskriptif dilakukan untuk mengetahui persebaran data dan uji asumsi klasik dilakukan untuk mengetahui distribusi data, multikolinearitas, heteroskedastisistas dan autokorelasi. Uji asumsi klasik dilakukan sebelum analisis regresi. Persamaan regresi berdasarkan hipotesis yang diusulkan adalah sebagaiberikut:

ICD $=\alpha+\beta_{1}$ LNSIZE $+\beta_{2}$ ROA $+\beta_{3}$ DAR + $\beta_{4} \mathrm{AUD}+\beta_{5} \mathrm{IND}+\beta_{6} \mathrm{R} \& \mathrm{D}+\varepsilon$

\section{Keterangan:}

ICD = Pengungkapan modal

intelektual

$$
\begin{array}{ll}
\alpha & =\text { Konstanta } \\
\beta_{1}-\beta_{6} & =\text { Koefisien regresi }
\end{array}
$$




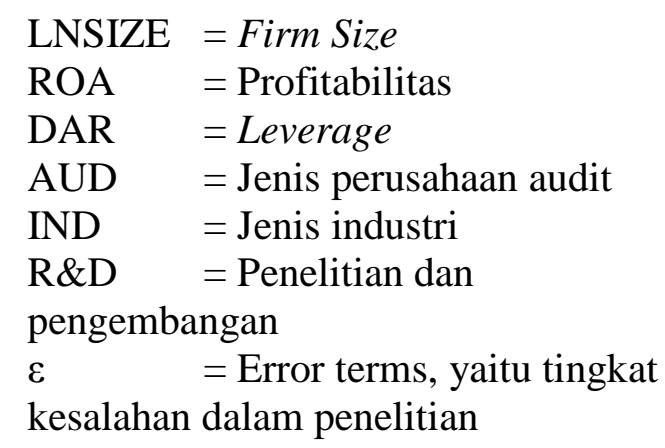

HASIL PENELITIAN

\section{Pemilihan Sampel}

Pemilihan sampel pada penelitian ini menggunakan metode purposive sampling berdasarkan kriteria yang telah ditetapkan. Setelah melalui tahap seleksi dalam menentukan sampel dan setelah dilakukan outlier diperoleh sampel berjumlah 261 perusahaan.

Tabel 1. Pemilihan Sample

Keterangan Jumlah

Tabel 2. Hasil Analisis Statistik Deskriptif

\begin{tabular}{|c|c|c|c|c|c|c|}
\hline \multirow{2}{*}{ Dummy } & \multicolumn{2}{|c|}{ AUD } & \multicolumn{2}{|c|}{ IND } & \multicolumn{2}{|c|}{$R \& D$} \\
\hline & $\mathrm{N}$ & $\%$ & $\mathrm{~N}$ & $\%$ & $\mathrm{~N}$ & $\%$ \\
\hline 0 & 149 & 57,1 & 137 & 52,5 & 231 & 88,5 \\
\hline 1 & 112 & 42,9 & 124 & 47,5 & 30 & 11,5 \\
\hline Total & 261 & 100 & 261 & 100 & 261 & 100 \\
\hline \multicolumn{5}{|c|}{$\begin{array}{l}\text { Perusahaan yang terdaftar di } \\
\text { BEI tahun } 2018\end{array}$} & \multicolumn{2}{|c|}{622} \\
\hline \multicolumn{5}{|c|}{$\begin{array}{l}\text { Perusahaan yang tidak sesuai } \\
\text { kriteria sampel }\end{array}$} & \multicolumn{2}{|c|}{ (346) } \\
\hline \multicolumn{5}{|c|}{ Data outlier } & \multicolumn{2}{|c|}{$(15)$} \\
\hline \multicolumn{5}{|c|}{$\begin{array}{l}\text { Jumlah data sampel yang } \\
\text { diperoleh }\end{array}$} & \multicolumn{2}{|c|}{261} \\
\hline
\end{tabular}

Sumber: Pengolahan data sekunder, 2020

\section{Statistik Deskriptif}

Analisis statistik deskriptif digunakan untuk melihat gambaran data dari variabel-variabel dalam penelitian ini. Tabel berikut ini menunjukkan gambaran data dari hasil pengolahan SPSS.

Tabel 3. Hasil Analisis Statistik Deskriptif Std. Deviati

\begin{tabular}{llllrc} 
Variabel & N & Min & Max & Mean & on \\
\hline LNSIZE & 261 & 10,86 & 20,98 & 15,46 & 1,8347 \\
\hline ROA & 261 & 0,028 & 46,66 & 5,76 & 6,3520 \\
\hline
\end{tabular}

\begin{tabular}{lrrrrr}
\hline DAR & 261 & 1,39 & 91,76 & 47,18 & 22,625 \\
& & & & & 5 \\
\hline AUD & 261 & 0 & 1 & 0,43 & 0,496 \\
\hline IND & 261 & 0 & 1 & 0,48 & 0,500 \\
\hline R\&D & 261 & 0 & 1 & 0,11 & 0,320 \\
\hline ICD & 261 & 23,44 & 68,75 & 47,63 & 8,0032 \\
\hline $\begin{array}{l}\text { Valid N } \\
\text { (listwise) }\end{array}$ & 261 & & & & \\
\hline
\end{tabular}

Sumber: Pengolahan data sekunder, 2020

Tabel 3 menunjukkan bahwa variabel yang digunakan dengan proksinya masingmasing memiliki nilai minimum, maksimum, rata-rata dan standar deviasi seperti pada tabel, dan terlihat bahwa jumlah sampel yang digunakan valid berjumlah 261. Ukuran perusahaan yang diproksikan dengan total aset yang di logaritma naturalkan memiliki nilai minimum 10,86 dan nilai maksimum 20,98. Profitabilitas yang diproksikan dengan ROA memiliki nilai minimum 0,028 dan nilai maksimum 46,66. Leverage yang diproksikan dengan DAR memiliki nilai minimum 1,39 dan nilai maksimum 91,76. Jenis perusahaan audit, jenis industri dan penelitian pengembangan yang menggunakan data dummy memiliki nilai minimum 0 dan nilai maksimum 1 . Pengungkapan modal intelektual (ICD) memiliki nilai minimum 23,4475 dan nilai maksimum 68,75.

Sumber: Pengolahan data sekunder, 2020

Tabel 3 menunjukkan sebaran data dari data dummy untuk variable jenis perusahaan audit, jenis industri, penelitian dan pengembangan. Jenis perusahaan audit (AUD) menunjukkan terdapat 149 perusahaan yang diaudit oleh KAP non big four, 112 perusahaan diaudit oleh KAP big four (KPMG, PWC, EY, Delloite). Jenis industri menunjukkan terdapat 137 perusahaan low-IC intensive industries dan 124 perusahaan high-IC intensive industries. Penelitian dan pengembangan (R\&D) menunjukkan terdapat 231 perusahaan yang tidak mengungkapkan atau melakukan penelitian dan pengembangan, dan hanya 30 perusahaan yang mengungkapkan atau melakukan penelitian dan pengembangan. 


\section{Uji Asumsi Klasik}

Uji asumsi klasik telah dilakukan dalam penelitian yang menunjukkan hasil bahwa data terdistribusi normal, tidak terjadi multikolinearitas, tidak terjadi heteroskedastisitas, tidak terjadi auto-korelasi sehingga data dapat dianalisis lebih lanjut dengan analisis regresi.

\section{Analisis regresi \\ (Uji koefisien determinasi, Uji F, Uji t) \\ Data yang telah memenuhi uji asumsi klasik maka selanjutnya dapat dilakukan analisis regresi. Analisis ini digunakan untuk mengetahui variabel bebas (independen) apa saja yang dapat mempengaruhi variabel terikat (dependen). Hasil analisis dari faktor- faktor yang mempengaruhi (determinan) pengungkapan modal intelektual dapat dilihat pada Tabel 4.}

Tabel 4. Hasil analisis regresi determinan pengungkapan modal intelektual

\begin{tabular}{lrrr}
\hline Variabel & Koefisien & t-hitung & Sig. \\
\hline (Constant) & 13,393 & 3,989 & 0,000 \\
LNSIZE & 1,846 & 7,444 & 0,000 \\
ROA & 0,073 & 1,200 & 0,231 \\
DAR & 0,051 & 2,685 & 0,008 \\
AUD & 1,790 & 2,214 & 0,028 \\
IND & 2,853 & 3,827 & 0,000 \\
R\&D & 6,570 & 5,897 & 0,000 \\
\hline Adjusted R & & & 0,507 \\
\hline F hitung & & 45,584 \\
\hline Sig. & & & 0,000 \\
\hline Sumber: Pengolahan data sekunder, 2020
\end{tabular}

Koefisien determinasi berguna untuk mengetahui sejauh mana suatu model dalam menerangkan variabel terikat (dependen) dengan nilai antara nol sampai dengan satu. Apabila nilai koefisien determinasi mendekati 1 berarti semakin baik model yang digunakan, karena variabel-variabel independen yang digunakan memiliki kemampuan dalam menerangkan variabel dependen dalam model. Berdasarkan tabel 4 dapat diketahui bahwa koefisien determinasi (adjusted $\mathrm{R}^{2}$ ) dari analisis regresi determinan pengungkapan modal intelektual adalah 0,507. Artinya 50,7\% pengungkapan modal intelektual dipengaruhi oleh firm size, profitabilitas, leverage, jenis perusahaan audit, jenis industri, penelitian dan pengembangan, sedangkan sisanya yaitu $49,3 \%$ pengungkapan modal intelektual dijelaskan oleh variabel-variabel lainnya yang tidak termasuk dalam penelitian ini.

Uji signifikansi simultan (uji F) dilakukan untuk menguji pengaruh variabel independen terhadap variabel dependen secara simultan (bersamaan). Berdasarkan tabel 4 maka variabel firm size, profitabilitas, leverage, jenis perusahaan audit, jenis industri, penelitian dan pengembangan secara simultan berpengaruh terhadap pengungkapan modal intelektual yaitu sebesar 45,584\% dengan nilai signifikansi sebesar 0,000 yang lebih kecil dari 0,05.

Berdasarkan tabel 4 maka dapat dibuat persamaan regresinya sebagai berikut:

ICD=13,393+1,846LNSIZE+0,073ROA+ 0,051DAR+1,790AUD+2,853IND+ $6,570 R \& D+\varepsilon$

Persamaan diatas dapat dilihat bahwa konstanta sebesar 13,393 menunjukkan bahwa apabila semua variabel independen diasumsikan 0 , maka pengungkapan modal intelektual secara konstan akan bernilai 13,393 .

Uji t pada dasarnya menunjukkan seberapa besar variabel independen secara parsial dalam menerangkan variabel dependen. Berdasarkan tabel 4 dapat dilihat bahwa variable profitabilitas menjadi satusatunya variabel yang tidak berpengaruh terhadap pengungkapan modal intelektual karena nilai signifikansinya lebih dari 0,05. Berikut ini adalah ringkasan hasil hipotesis berdasarkan tabel 4 .

Tabel 5.Ringkasan Hasil Hipotesis

\begin{tabular}{llll}
\hline Hipotesis & B & Sig. & Keputusan \\
\hline H1 & 1,846 & 0,000 & Diterima \\
\hline H2 & 0,073 & 0,231 & Ditolak \\
\hline H3 & 0,051 & 0,008 & Diterima \\
\hline H4 & 1,790 & 0,028 & Diterima \\
\hline H5 & 2,853 & 0,000 & Diterima \\
\hline H6 & 6,570 & 0,000 & Diterima
\end{tabular}

Sumber: Pengolahan data sekunder, 2020 


\section{Pembahasan}

Hipotesis 1 pada penelitian ini diterima dengan koefisien regresi 1,846 dan tingkat signifikansi 0,000 artinya firm size terbukti berpengaruh positif terhadap pengungkapan modal intelektual. Hal ini menunjukkan bahwa firm size yang semakin besar maka akan melakukan pengungkapkan modal intelektual lebih banyak tujuannya adalah untuk mengurangi konflik kepentingan yang terjadi antara prinsipal dan agen. Pengungkapan modal intelektual oleh perusahaan besar dilakukan dengan harapan dapat minimalisasi biaya keagenan yang akan menjadi beban perusahaan. Penelitian ini menunjukkan hasil yang konsisten dengan penelitian-penelitian yang dilakukan oleh Utomo dan Chariri (2015), Bruggen (2009), Oliveira et al. (2006).

Hipotesis 2 pada penelitian ini ditolak dengan koefisien regresi 0,073 dan tingkat signifikansi 0,231 artinya profitabilitas terbukti tidak berpengaruh terhadap pengungkapan modal intelektual. Hal ini menunjukkan bahwa perusahaan yang konsisten memiliki profitabilitas di setiap tahunnya maka perusahaan telah mempunyai kondisi keuangan yang baik, sehingga perusahaan tidak perlu mengungkapkan modal intelektual yang banyak karena manajemen perusahaan menganggap stakeholders sudah memahami kondisi perusahaan yang memang memiliki prospek yang baik dimasa depan. Penelitian ini menunjukkan hasil yang konsisten dengan penelitian yang dilakukan Stephani dan Yuyetta (2011) yang membuktikan bahwa profitabilitas tidak berpengaruh terhadap pengungkapan modal intelektual.

Hipotesis 3 pada penelitian ini diterima dengan koefisien regresi 0,051 dan tingkat signifikansi 0,008 artinya leverage berpengaruh positif terhadap pengungkapan modal intelektual. Hal ini menunjukkan bahwa perusahaan yang memiliki tingkat utang yang tinggi akan lebih banyak melakukan pengungkapan modal intelektual karena untuk menunjukkan kepada stakeholder bahwa meskipun perusahaan memiliki utang yang tinggi akan tetapi perusahaan yakin dengan modal intelektual yang dimiliki akan dapat mengatasi utang yang dimiliki baik utang jangka pendek maupun jangka panjang. Penelitian ini menunjukkan hasil yang konsisten dengan penelitian yang telah dilakukan White et al. (2007), Dammak et al. (2008).

Hipotesis 4 pada penelitian ini diterima dengan koefisen regresi 1,790 dan tingkat signifikansi 0,028 artinya perusahaan yang diaudit oleh KAP big four melakukan pengungkapan modal intelektual lebih banyak. Hal ini karena KAP big four telah memiliki reputasi yang sangat baik sehingga akan memberi saran ke manajemen perusahaan yang diaudit untuk mengungkapkan informasi apa saja yang berguna untuk para investor sehingga investor dapat melihat transparansi informasi yang disampaikan perusahaan secara lengkap dan terperinci. Hasil penelitian ini sejalan dengan penelitian Woodcock dan Whiting (2009).

Hipotesis 5 pada penelitian ini diterima dengan koefisien regresi 2,853 dan tingkat signifikansi 0,000 artinya perusahaan yang masuk kategori high-IC intensive industries melakukan pengungkapan modal intelektual lebih banyak. Beberapa perusahaan kategori high-IC intensive industries diantaranya Astra International Tbk dengan indeks ICD 60,94\%, Astra Otoparts Tbk dengan indeks ICD 64,06\%, Bank Central Asia Tbk $68,75 \%$, Bank Rakyat Indonesia Tbk dengan indeks ICD 67,19\%, PT Telekomunikasi Indonesia dengan indeks ICD 65,63\%. Penelitian ini menunjukkan hasil yang sama dengan penelitian Puteri dan Chariri (2016).

Hipotesis 6 pada penelitian ini diterima dengan koefisien regresi 6,570 dan tingkat signifikansi 0,000 artinya perusahaan yang melakukan penelitian dan pengembangan melakukan pengungkapan modal intelektual lebih banyak. Hal ini menunjukkan bahwa perusahaan yang melakukan penelitian dan 
pengembangan menyadari bahwa $R \& D$ tidak dapat dirasakan manfaatnya secara langsung sehingga perusahaan harus melakukan pengungkapan lebih banyak pada pengungkapan modal intelektual terkait pencapaian-pencapaian yang telah diperoleh dalam melakukan penelitian dan pengembangan. Harapannya investor akan memiliki perhatian lebih pada perusahaan ini dibandingkan pada perusahaan yang tidak melakukan penelitian dan pengembangan.

Uji beda rata-rata digunakan dalam penelitian ini untuk membuktikan apakah terdapat perbedaan mean antara dua kelompok. Pengujian ini digunakan untuk melihat apakah perusahaan yang diaudit oleh KAP big four, perusahaan yang masuk kategori hihg-IC intensive industries, perusahaan yang melakukan penelitian dan pengembangan melakukan pengungkapan modal intelektual yang lebih banyak. Hasilnya pengujiannya dapat dilihat pada tabel 6 , tabel 7 dan tabel 8. Perusahaan yang diaudit oleh KAP big four melakukan pengungkapan modal intelektual lebih banyak, hal ini dapat dilihat dari hasil uji pada tabel 6 berikut ini:

Tabel 6. Group Statistic

\begin{tabular}{|c|c|c|c|}
\hline & AUD & $\mathrm{N}$ & Mean \\
\hline \multirow[t]{2}{*}{ ICD } & 0 (Non Big four) & 149 & 44,99 \\
\hline & 1 (Big Four) & 112 & 51,14 \\
\hline
\end{tabular}

Sumber: Pengolahan data sekunder, 2020

Perusaahaan yang diaudit oleh KAP big four menunjukkan rata-rata pengungkapan modal intelektual lebih tinggi yaitu dengan rata-rata indeks ICD sebesar $51,14 \%$ sedangkan perusahaan yang diaudit oleh KAP non big four menunjukkan rata-rata indeks ICD sebesar $44,99 \%$.

Perusahaan yang masuk kategori high-IC intensive industries melakukan pengungkapan modal intelektual lebih banyak, hal ini dapat dilihat dari hasil uji pada tabel 7 berikut ini:
Tabel 7. Group Statistic

\begin{tabular}{|c|c|c|c|}
\hline & IND & $\mathrm{N}$ & Mean \\
\hline \multirow[t]{2}{*}{ ICD } & 0 (Low-IC) & 137 & 45,07 \\
\hline & 1(High-IC) & 124 & 50,47 \\
\hline
\end{tabular}

Sumber: Pengolahan data sekunder, 2020

Perusaahaan yang masuk kategori high-IC intensive industries menunjukkan rata-rata pengungkapan modal intelektual lebih tinggi yaitu dengan rata-rata indeks ICD sebesar $50,47 \%$ sedangkan perusahaan low-IC intensive industries menunjukkan rata-rata indeks ICD sebesar 45,07\%.

Perusahaan yang melakukan penelitian dan pengembangan melakukan pengungkapan modal intelektual lebih banyak, hal ini dapat dilihat dari hasil uji pada tabel 8 berikut ini:

Tabel 8. Group Statistic

\begin{tabular}{c|lcc}
\hline \multicolumn{1}{c}{ R\&D } & $\mathrm{N}$ & Mean \\
\hline \multirow{2}{*}{ ICD } & 0 (Non R\&D) & 231 & 46,65 \\
\cline { 2 - 4 } & 1 (R\&D) & 30 & 55,21 \\
\hline
\end{tabular}

Sumber: Pengolahan data sekunder, 2020

Perusaahaan yang melakukan penelitian dan pengembangan menunjukkan rata-rata pengungkapan modal intelektual lebih tinggi yaitu dengan rata-rata indeks ICD sebesar $55,21 \%$ sedangkan perusahaan yang tidak melakukan penelitian dan pengembangan menunjukkan rata-rata indeks ICD sebesar $46,65 \%$.

\section{KESIMPULAN DAN KETERBATASAN}

Penelitian ini menguji karakteristik perusahaan sebagai determinan pengungkapan modal intelektual. Satu dari enam hipotesis yang diajukan memiliki hasil yang berbeda yaitu pada hipotesis kedua. Hasilnya menunjukkan bahwa hipotesis kedua ditolak, karena tingkat signifikansinya lebih besar dari 0,05, sedangkan 5 hipotesis lainnya yang diusulkan menunjukkan hasil diterima. Determinan yang mempengaruhi pengungkapan modal intelektual diantaranya firm size, leverage, jenis perusahaan audit, jenis industri, penelitian dan pengembangan. Satu variabel yaitu profitabilitas yang diproksikan dengan ROA ditolak sebagai determinan pengungkapan modal intelektual.

Penelitian ini memiliki keterbatasan 
diantaranya subjektivitas yang terjadi dan tidak dapat dihindari ketika melakukan analisis konten item-item pengungkapan modal intelektual. Beberapa item ICD-In diungkapkan dalam laporan tahunan dengan istilah yang berbeda tetapi memiliki arti yang sama. Salah satu contohnya adalah dalam daftar item terdapat item pengungkapan dengan istilah kode etik namun di laporan tahunan perusahaan diungkapkan dengan istilah kode tata laku, tatanan perilaku, pedoman perilaku, sehingga perbedaan istilah tersebut menjadikan identifikasi itemitem pengungkapan modal intelektual semakin sulit. Hal ini berakibat pada waktu yang dibutuhkan untuk melakukan analisis konten item-item pengungkapan modal intelektual yang semakin lama. Harapannya kedepan terdapat standar dalam pengungkapan modal intelektual sehingga item-item pengungkapan antara satu perusahaan dan perusahaan lainnya memiliki keseragaman nama.

Saran untuk penelitian kedepan bagi para peneliti yang ingin meneliti topik ini disarankan untuk melakukan penginputan (analisis konten) item-item pengungkapan modal intelektual secara hati-hati dan teliti serta dilakukan jauh jauh hari karena terdapat banyak item dalam pengungkapan modal intelektual yang akan membutuhkan waktu yang lama. Penelitian selanjutnya juga diharapkan dapat menambah variabelvariabel apa saja yang mungkin menjadi determinan atau anteseden pengungkapan modal intelektual. Penelitian selanjutnya juga diharapkan lebih teliti dan berhati-hati pada saat melakukan konten analisis item-item pengungkapan modal intelektual dikarenakan ada item-item indikator pengungkapan modal intelektual yang memiliki istilah berbeda-beda pada setiap laporan tahunan yang dipublikasikan oleh masing-masing perusahaan akan tetapi memiliki arti atau makna yang sama.

\section{Ucapan Terima Kasih}

Ucapan terimakasih kepada Kementerian Riset dan Teknologi/Badan Riset dan Inovasi Nasional Republik Indonesia yang telah memberikan hibah penelitian dosen pemula kepada penulis.

\section{DAFTAR PUSTAKA}

Brosnan, S., \& Flynn, A. (2004). The Economic Value of Intellectual Capital. IAFA Annual Conference. Queens University Belfast.

Bruggen, A., Vergauwen, P., \& Dao, M. (2009). Determinants of Intellectual Capital Disclosure: Evidence from Australia. Management Decision Vol. 47 No. 2, 233245.

Dammak, S., Triki, M., dan Boujelbene, Y. 2008. A Study on Intellectual Capital Disclosure Determinants inThe European Context. International Journal of Learning and Intellectual Capital. Volume 5, Issue 3-4, 2008, pp 417-430.

Guthrie, J., Petty, R., Ferrier, F., \& Wells, R. (1999).

There is No Accounting for Intellectual Capital in Australia: Review of Annual Reporting Practices and the Internal Measurement of Intangibles within Australian Organisations. International Symposium Measuring and Reporting Intellectual Capital: Experiences, Issues and Prospects.

Hooks, J., \& Staden, C. J. (2011). Evaluating Environmental Disclosures: the Relationship between Quality and Extent Measures. The British Accounting Review, Vol. 43, 200-213.

Hutomo, Y. P., Lstari, D. D., \& Mukmin, M. N. (2019). Perputaran Modal Kerja, Pertumbuhan Penjualan, Leverage, Dan Profitabilitas: Kajian Terhadap Perusahaan Sektor Industri Barang Konsumsi Yang Terdaftar Di Bursa Efek Indonesia. JURNAL AKUNIDA, 5(2), 1-14.

Jensen, M., \& Meckling, W. (1976). Theory of the Firm: Managerial Behavior, Agency 
Costs and Ownership Structure Journal of Financial Economics, 3(4), 305-306.

Khasanah, I., \&Nahumury, J. (2013). The Factors Affecting Auditor Switching in Manufacturing Companies Listed in Indonesia Stock Exchange (BEI). The Indonesia Accounting Review Vol. 3, No. 2 , 203-212.

Melani, M. M. (2017). Pengaruh Efesiensi, Efektifitas Assets Terhadap Leverage Dan Dampaknya Terhadap Return Saham Pada Perusahaan Sektor Pertambangan Batu Bara Yang Terdaftar Di Bursa Efek Indonesia Periode Tahun 2009. 2014. JURNAL AKUNIDA, 3(2), 25-32.

Oliviera, L., Rodrigues, L., \& Craig, R. (2006). Firm Specific Determinants on Intangibles Reporting Evidence from The Portugese Stock Market. Journal of Human Resources Costing and Accounting, 11-33.

Puteri, I. N., \& Chariri, A. (2016). Anteseden dan Konsekuensi Intellectual Capital Disclosure. Simposium Nasional Akuntansi XIX, (hal. 1-29). Lampung.

Redhita, D., \& Mayangsari, S. (2016). FaktorFaktor yang Mempengaruhi Pengungkapan Modal Intelektual. Media Riset Akuntansi, Auditing \& Informasi, Vol. 16 No. 2. Universitas Trisakti.

Roos, J., Roos, N. C., \& Edvinsson, L. (1997). Intellectual Capital. London: Macmillan Business.

Saleh, N. M., Rahman, M. R., \& Hassan, M. S. (2009). Ownership Structure and Intellectual Capital Performance in Malaysia. Asian Academy of Management Journal of Accounting and Finance, Vol. 5, No. 1, 1-29.

Stephani, T., \& Yuyetta, E. N. (2011). Analisis Faktor-faktor yang Mempengaruhi Intellectual Capital Disclosure (ICD). Jurnal Akuntansi \& Auditing, Volume 7, 111 - 121.
Sudana, I. M. (2011). Manajemen Keuangan Perusahaan Teori dan Praktik. Jakarta: Erlangga.

Suhardjanto, D., \& Wardhani, M. (2010). Praktik Intellectual Capital Disclosure Perusahaan yang Terdaftar di Bursa Efek Indonesia. JAAI Vol. 14 No. 1, 71-85.

Sukmadinata, N. S. (2008). Metode Penelitian Pendidikan. Bandung: Remaja Rosdakarya.

Susandra, F. (2015). Analisis Pemilihan Model Prediktor Financial Distressterbaik (Perbandingan Antara The Zmijewski Model, The Ohlson Model, The Altman Model, Dan The Springate Model). JURNAL AKUNIDA, 1(2), 6170.

Taliyang, S. M., Latif, R. A., \& Mustafa, N. H. (2011). The Determinants of Intellectual Capital Disclosure Among Malaysian Listed Companies. International Journal Of Management and Marketing Research, Vol. 4, 25-33.

Tan, H. P., Plowman, D., \& Hancock, P. (2007). Intellectual Capital and Financial Returns of Companies. Journal of Intellectual Capital, Vol. 8 Iss: 1, 76 - 95.

Ulum, I. (2015). Intellectual Capital Disclosure: Suatu Analisis dengan Four Way Numerical Coding System. JAAI, Vol. 19 No. 1, 39-50.

Utomo, A. I. (2015). Faktor-Faktor yang Mempengaruhi Pengungkapan Modal Intelektual dan Dampaknya terhadap Nilai Perusahaan. Fakultas Ekonomika dan Bisnis Universitas Diponegoro.

Utomo, A. I., \& Chariri, A. (2015). Faktor-Faktor yang Mempengaruhi Pengungkapan Modal Intelektual dan Dampaknya terhadap Nilai Perusahaan. Simposium Nasional Akuntansi XVII, (hal. 1-12). Medan.

White, G., Lee,A. dan Tower G. 2007. Driver of Voluntary Intellectual Capital Disclosure in Listed Biotechnology Companies. Journal of Intellectual Capital. Vol. 8, No. 3, pp. 517-537.

Woodcock, J., \& Whiting, R. H. (2009). Intellectual Capital Disclosures by Australian 
Companies. AFAANZ Conference, (hal. 1-31). Adelaide, Australia.

Zurnali, C. (2010). Learning Organization, Competency, Organizational Commitment, and Customer Orientation: Knowledge WorkerKerangka Riset Manajemen Sumber Daya Manusia Masa Depan. Bandung: Unpad Press. 